\title{
Combinations of physiologic estrogens with xenoestrogens alter calcium and kinase responses, prolactin release, and membrane estrogen receptor trafficking in rat pituitary cells
}

Yow-Jiun Jeng, Mikhail Kochukov, Cheryl S Watson*

\begin{abstract}
Background: Xenoestrogens such as alkylphenols and the structurally related plastic byproduct bisphenol A have recently been shown to act potently via nongenomic signaling pathways and the membrane version of estrogen receptor- $\alpha$. Though the responses to these compounds are typically measured individually, they usually contaminate organisms that already have endogenous estrogens present. Therefore, we used quantitative mediumthroughput screening assays to measure the effects of physiologic estrogens in combination with these xenoestrogens.
\end{abstract}

Methods: We studied the effects of low concentrations of endogenous estrogens (estradiol, estriol, and estrone) at $10 \mathrm{pM}$ (representing pre-development levels), and $1 \mathrm{nM}$ (representing higher cycle-dependent and pregnancy levels) in combinations with the same levels of xenoestrogens in $\mathrm{GH}_{3} / \mathrm{B} 6 / \mathrm{F} 10$ pituitary cells. These levels of xenoestrogens represent extremely low contamination levels. We monitored calcium entry into cells using Fura-2 fluorescence imaging of single cells. Prolactin release was measured by radio-immunoassay. Extracellular-regulated kinase (1 and 2) phospho-activations and the levels of three estrogen receptors in the cell membrane (ERo, ERR, and GPER) were measured using a quantitative plate immunoassay of fixed cells either permeabilized or nonpermeabilized (respectively).

Results: All xenoestrogens caused responses at these concentrations, and had disruptive effects on the actions of physiologic estrogens. Xenoestrogens reduced the \% of cells that responded to estradiol via calcium channel opening. They also inhibited the activation (phosphorylation) of extracellular-regulated kinases at some concentrations. They either inhibited or enhanced rapid prolactin release, depending upon concentration. These latter two dose-responses were nonmonotonic, a characteristic of nongenomic estrogenic responses.

Conclusions: Responses mediated by endogenous estrogens representing different life stages are vulnerable to very low concentrations of these structurally related xenoestrogens. Because of their non-classical dose-responses, they must be studied in detail to pinpoint effective concentrations and the directions of response changes.

\section{Background}

Xenoestrogens are small lipophillic molecules that mimic physiological estrogens [1], and whose exposures have been linked to a variety of disease states [2-11], even when present at concentrations far below those currently allowed by federal regulations. We previously

\footnotetext{
* Correspondence: cswatson@utmb.edu

* Correspondence: cswatson@utmb.edu Medical Branch, Galveston, Texas, USA
}

found that both physiologic estrogen metabolites and a number of environmental estrogens have potent activities via the nongenomic pathway of estrogen signaling [12-19], whereas they have been shown to be rather weak via genomic signaling mechanisms [20-25]. Therefore, inactivity in genomic assays does not necessarily predict the same via nongenomic mechanisms. A variety of xenoestrogens representing different chemical and use classes has been examined for nongenomic signaling 


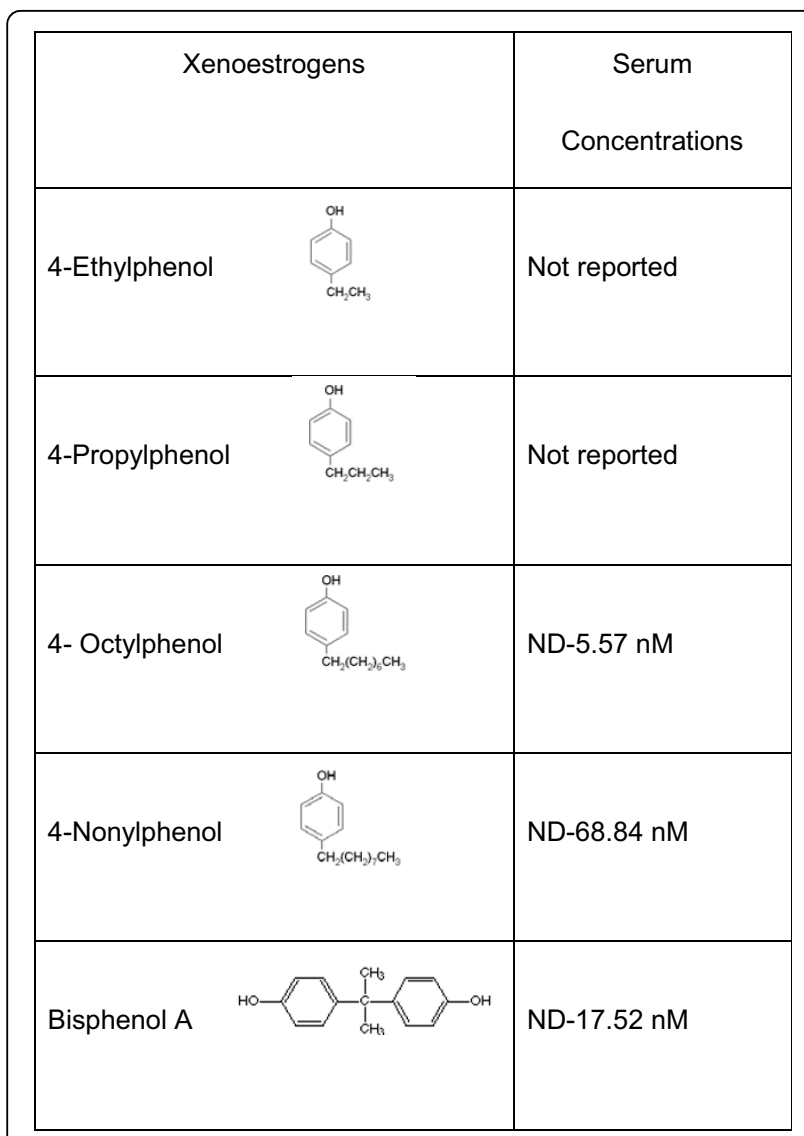

Figure 1 Chemical structures and reported serum levels of xenoestrogens used in our study [26-29]. ND (non-detectable).

pathway activities. Alkylphenols are of particular interest, as they represent a structurally related set of compounds that differ in the lengths of their carbon side-chain modifications at position 4 on the phenol ring, or in the case of bisphenol A (BPA) have another phenolic ring in place of the side-chain (see Figure 1 for structures and human blood levels [26-29]). The use of alkylphenols as industrial surfactants results in contamination of many of our waterways $[30,31]$. BPA can contaminate the environment in significant amounts by leaching from products (plastic food and water containers, dental sealants, and some cash register receipts), and as byproducts of manufacturing [32-34].

There are three candidate estrogen receptors (ERs) via which estrogenic and xenoestrogenic responses can operate. The classical ERs $\alpha$ and $\beta$ have been described in the membrane of these and other cells [35-43]. GPER is a transmembrane ER in the GPCR family. It has been shown to mediate a wide range of responses to estrogens in different cell types [44]. Because many of the endpoints that it drives are different than those of the classical ERs $\alpha$ and $\beta$ (though often using overlapping signaling pathways) [45], it may be a complementary estrogen signaling system in ways that we do not yet fully understand. Estrogens bind with different affinities to these different ER types $[46,47]$, which could provide diverse physiological outcomes in unique circumstances or stages of development.

We previously compared the signaling activities of many physiological estrogens and xenoestrogens to those of estradiol $\left(E_{2}\right)$ in pituitary and neuronal cells, gaining some insight into how their chemical structure may correlate with their estrogenic activity $[1,15]$. These compounds signal predominantly via membrane receptors for $\mathrm{ER} \alpha(\mathrm{mER} \alpha)[15,18,19]$, with compensatory actions sometimes occurring via mER $\beta$ or GPER when they are simultaneously present with $\mathrm{mER} \alpha$ [42]. Other studies have also demonstrated potent activities of some of these xenoestrogens in pancreatic islet cells [10], neuronal cells and tissues $[48,49]$, cells of the immune system $[8,50]$, and a wide variety of other cell or tissue experimental systems [51]. There are also many more studies describing the activities of these compounds at much higher concentrations, which may or may not act via receptors, but have limited applicability to our concern about prevalent environmental concentrations. Lifelong exposure to $E_{2}$ and potent synthetic estrogens is also known to be an important consideration for the development of cancers in reproductive tissues [52-55], so there is a possibility that xenoestrogens could likewise contribute to these types of disease. Xenoestrogens can cause proliferation of cells, as we demonstrated for octylphenol (OP), nonylphenol (NP), and BPA in our $\mathrm{GH}_{3} / \mathrm{B} 6 / \mathrm{F} 10$ cell model ([15] and reports cited therein).

Few studies have examined the ability of low concentrations of xenoestrogens in combination with physiologic estrogens to alter their responses. In some cases the combined presence of these estrogens can be inferred because the studies were done in gonadally intact animals or in tissues isolated from such animals treated in vivo $[8,49,56-59]$. Because of the non-monotonic concentration-responses typical of nongenomic estrogenic responses [12,13,15,17,19,42,60,61], wide concentration ranges and multiple combinations must be assessed using quantitative, relatively high-throughput endpoints to determine the real profile of xenoestrogen dose-based activities. Here we extend our earlier assays of individual estrogens and xenoestrogens shown to be active in nongenomic responses, to assays of their combinatorial effects. We have developed these assays in pituitary cells, where the responses relate to a variety of cellular responses and functions, including intracellular calcium (Ca) levels; the phospho-activation of extracellular regulated kinases (ERKs 1 and 2) as representatives of the mitogen-activated protein kinase (MAPK) family often involved in cellular remodeling, proliferation or death; 
and the release by the pituitary of a major peptide hormone, prolactin (PRL).

$\mathrm{E}_{2}$ (in the pM to $\mathrm{nM}$ range) is the physiologic estrogen most often associated with female development and specific reproductive function (see Figure 2). Relevant concentrations range across more than two orders of magnitude from early developmental levels up to those that direct function during the reproductive years. However, other endogenous estrogens such as estrone $\left(E_{1}\right)$ and estriol $\left(E_{3}\right)$ are more prevalent during other life phases, and may have significant effects on tissue development, function, and disease states. $E_{1}$ is a significant estrogenic hormone contributor in both reproductive ( 0.5-10 $\mathrm{nM})$ and postmenopausal (150-200 pM) women, and in men; $E_{3}$ levels are much higher in pregnant $(\sim 10-100 \mathrm{nM})$ than in nonpregnant $(<7 \mathrm{nM})$ women [62]. Low $\mathrm{E}_{3}$ levels in pregnancy have been associated with complications of eclampsia [63] and the incidence of Down's syndrome in offspring [64]. All three of these endogenous estrogens are also produced by aromatases in a number of non-reproductive tissues, where their effects may extend beyond reproductive functions [65]. One example is that $E_{3}$ has protective effects against the development of arthritis in certain experimental models [66], as had been known previously for $E_{2}$. Effects in brain, bone, the cardiovascular system, and many other tissues may be affected differentially by these three endogenous estrogenic compounds during different life stages; therefore, loss or enhancement of these effects due to interference by xenoestrogenic compounds could affect human health in a large number of tissues. Though it has recently been determined that $E_{1}$ and $E_{3}$ can act potently via nongenomic steroid signaling mechanisms in several tissues, including pituitary and neuronal cells $[12,13,67,68]$, we do not know if xenoestrogens can interfere with these activities when they are present in combination, as is typical with exposures to humans and animals living in a contaminated environment.

The subcellular trafficking of signaling proteins is a critical consideration for their function, because many actions require close associations of cross-activating and signal-transducing proteins. In this regard, steroid receptors have been found to reside in the caveolar subcompartment of plasma membranes [69-71] in addition to the nuclear compartment, and the entry and exit of proteins from these compartments, and locations in between, tells part of the story of their participation in cellular regulation. We have recently found in other systems and with other estrogens that estrogenic actions can also lead to trafficking of ERs in and out of the plasma membrane $[13,42]$. Here we look at changes in

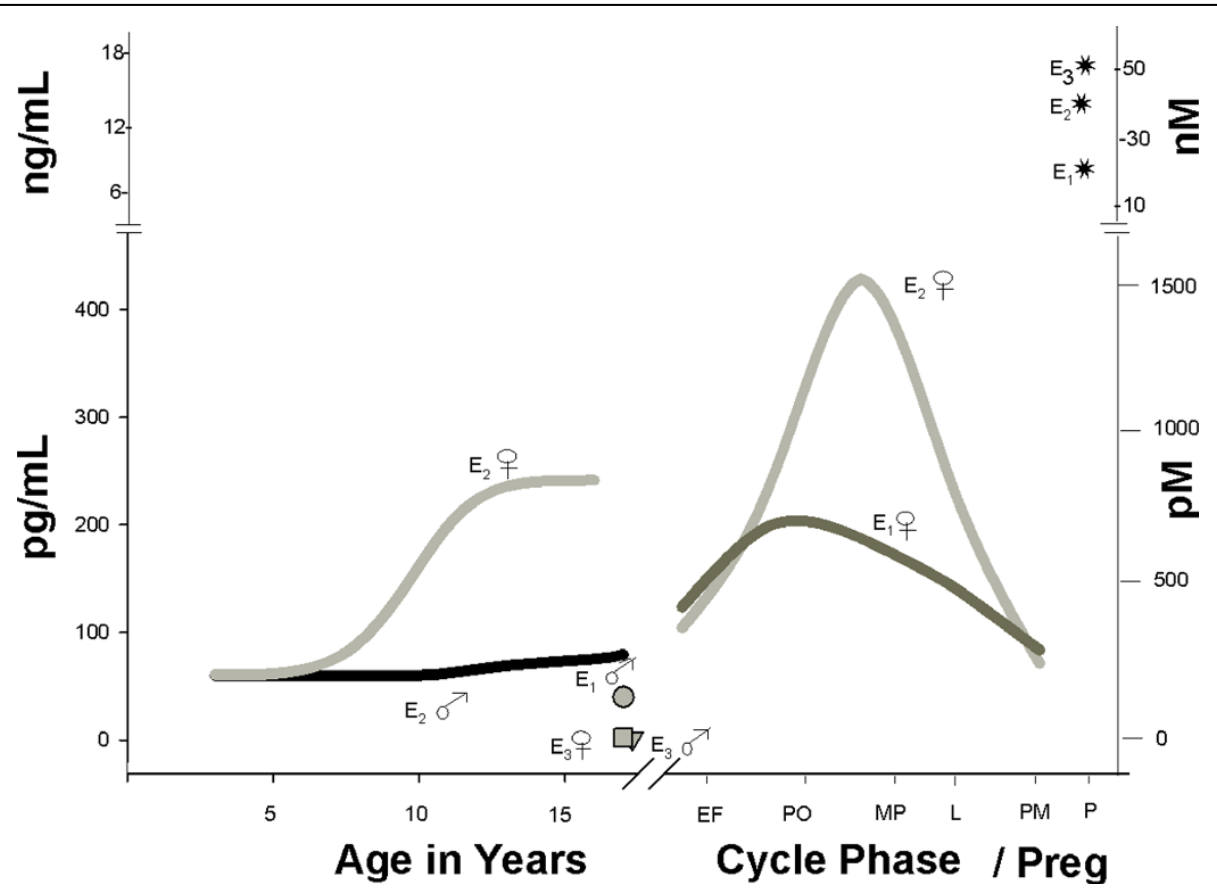

Figure 2 Levels of physiologic estrogens during different life stages in females compared to males. These data were graphed from information summarized in a textbook [62], and span concentrations over 2 orders of magnitude. Levels over time and different stages are shown by lines, and point values are shown as symbols, all labeled directly on the graph. Cycle phases are labeled on the timeline as EF (early follicular), PO (preovulatory), MP (mid cycle-peak), L (luteal), PM (post menopausal), and P (pregnant, peak levels). The levels of the estrogens estrone, estradiol, and estriol $\left(E_{1}, E_{2}\right.$, and $E_{3}$, respectively) are shown for females (Q) and males (o") 
the membrane location of ERs to better understand how xenoestrogens may alter the nongenomic actions of physiologic estrogens by re-locating their receptors to sites where nongenomic signaling partners may be less available.

Our tests of physiologic estrogens examine concentrations that might be experienced due to normal mammalian levels of the endogenous hormones at different life stages. A 10 pM concentration would approximate early developmental (infant) levels (see Figure 2), and a 100x higher $1 \mathrm{nM}$ concentration of these hormones would approximate concentrations experienced during menstrual cycling or early pregnancy. We then superimposed upon those endogenous estrogen levels a frequently encountered very low contaminant concentration range of alkylphenols and BPA (10 pM and $1 \mathrm{nM})$ to see how normal signaling and functional endpoints would be affected.

\section{Methods}

\section{Materials and treatments}

We purchased phenol red-free Dulbecco modified Eagle medium (DMEM, high glucose) from Mediatech (Herndon, VA); horse serum from Gibco BRL (Grand Island, NY); defined supplemented calf sera and fetal bovine sera from Hyclone (Logan, UT). Paraformaldehyde and picric acid were purchased from Fisher Scientific (Pittsburgh, PA). BPA (bisphenol A), EP (4-n-ethylphenol), PP (4-n-propylphenol), OP (4-n-octylphenol), and NP (4-n-nonylphenol), and other materials were purchased from Sigma (St. Louis, MO). The antibody (Ab) for phosphorylated (pERK) was purchased from Cell Signaling Technology (Danvers, MA), for clathrin (mouse anti-clathrin monoclonal) from ICN Biomedicals (Aurora, $\mathrm{OH})$, for ER $\alpha$ (MC-20) from Santa Cruz Biotechnology (Santa Cruz, CA), for ERß (Clone9.88) from Sigma, and for GPER (NLS4271) from Novus (Littleton, $\mathrm{CO})$. Vectastain ABC kits and biotin-conjugated secondary Abs were purchased from Vector Labs (Burlingame, CA). $\mathrm{GH}_{3} / \mathrm{B} 6 / \mathrm{F} 10$ cells were routinely propagated in DMEM containing $12.5 \%$ horse serum, $2.5 \%$ defined supplemented calf serum, and $1.5 \%$ fetal calf serum. Cells were used between passages 10 and 20 and placed in defined or charcoal-stripped serum-containing media before assays for estrogenic activity.

\section{Cytosolic free calcium ([Ca $\left.{ }^{2+}\right]$ i) fluorescent imaging} Cells were plated on poly-D-Lysine-treated 35/22 mm glass bottom dishes (Willco Wells, Amsterdam, Netherlands) at a density of 100,000 cells $/ \mathrm{mm}^{3}$. After $48-72 \mathrm{~h}$ of culture, the cells were loaded with the calcium-sensitive fluorescent dye Fura-2AM (Molecular Probes, Eugene, OR) at $2.5 \mu \mathrm{M}(1 \mathrm{~h}, \mathrm{RT})$, washed in a physiologic solution $\left(150 \mathrm{mM} \mathrm{NaCl}, 5.5 \mathrm{mM} \mathrm{KCl}, 1 \mathrm{mM} \mathrm{MgCl}_{2}\right.$,
$4 \mathrm{mM} \mathrm{CaCl}_{2}, 7 \mathrm{mM}$ glucose, $10 \mathrm{mM}$ HEPES, $\mathrm{pH}$ 7.4), and incubated at RT for 1-4 h before live $\mathrm{Ca}$ imaging. The imaging setup included a Nikon 200E microscope with $40 \times$ SuperFluo lens and computer-controlled illumination system (Sutter Instruments, Novato, CA) equipped with a digital monochrome-cooled chargecoupled device Roper Coolsnap HQ camera (Roper Scientific, Tucson, AZ). Fluorescent emissions at 510 $\mathrm{nm}$ from regions corresponding to a single cell were acquired online with the MetaFluor software (Universal Imaging, Downington, PA). The signals were obtained in dual 340 and $380 \mathrm{~nm}$ excitation mode and the average intensity of fluorescence in each region was used to estimate 340:380 ratios $(R)$, reflecting $\left[\mathrm{Ca}^{2+}\right]$ i. MetaMorph (Universal Imaging, Downington, PA) and SigmaPlot (Systat Software, San Jose, CA) scientific software were used for conversion and analysis of the acquired data. For quantitative measurement of changes in live cells for $\left[\mathrm{Ca}^{2+}\right] \mathrm{i}$ and oscillation frequency, the AutoFit function of PeakFit software (Systat Software, San Jose, CA) was used, with manual adjustments. The peak threshold was chosen empirically as $\Delta R \geq 0.05$. Individual cells were considered responsive to estrogen treatment when they demonstrated increases in $\left[\mathrm{Ca}^{2+}\right] \mathrm{i}$ oscillation frequency of at least 0.25 calcium spikes per min (estimated during $10 \mathrm{~min}$ time interval) compared to the basal level, and delayed by no more than $10 \mathrm{~min}$ from the addition of any estrogen into the bath. Subsequent comparative analysis of cell responses was performed on responsive cells only for changes in intracellular $\mathrm{Ca}$ levels $\left(\Delta \mathrm{Ca} / \Delta \mathrm{Ca}_{0}\right.$; Figure $\left.3 \mathrm{D}-\mathrm{F}\right)$ and changes in $(\triangle \mathrm{Ca})$ oscillation frequency (Figure $3 \mathrm{G}-\mathrm{I})$.

\section{Quantitative ERK phosphorylation and mER assays}

We developed this assay to assess levels of activated ERKs 1 and 2 in fixed $\mathrm{GH}_{3} / \mathrm{B} 6 / \mathrm{F} 10$ cells [72]. Cells were plated at 10,000 cells/well in poly-D-lysine-coated 96well plates, and growth media were replaced the next day with DMEM containing $1 \%$ charcoal-stripped $(4 \times)$ serum for $48 \mathrm{hr}$. Cells were then washed and treated with different estrogenic compounds in medium for $5 \mathrm{~min}$, fixed with $2 \%$ paraformaldehyde $/ 0.2 \%$ picric acid at $4{ }^{\circ} \mathrm{C}$ for 48 $\mathrm{hr}$, then permeabilized with $\mathrm{PBS} / 2 \% \mathrm{BSA} / 0.1 \%$ Triton $\mathrm{X}-100$ for $1 \mathrm{hr}$ at RT. Cells were washed $3 \times$ with PBS and treated with primary Ab against pERKs ( $\mathrm{p}-\mathrm{Thr} 202$ / Tyr204; 1:400 in PBS/1\% BSA). After overnight incubation at $4{ }^{\circ} \mathrm{C}$, the cells were processed for signal development with the Vectastain $\mathrm{ABC}$ kit (Vector Labs, Burlingame, CA) as recommended by the company. Biotin-conjugated secondary Ab was used at a 1:300 dilution. Plates were incubated in the dark for $20 \mathrm{~min}$ at $37^{\circ} \mathrm{C}$ for the generation of alkaline phosphatase product (paranitrophenol) and read at $\mathrm{A}_{405}$ in a model 1420 Wallace microplate reader (Perkin Elmer, Waltham, MA). 


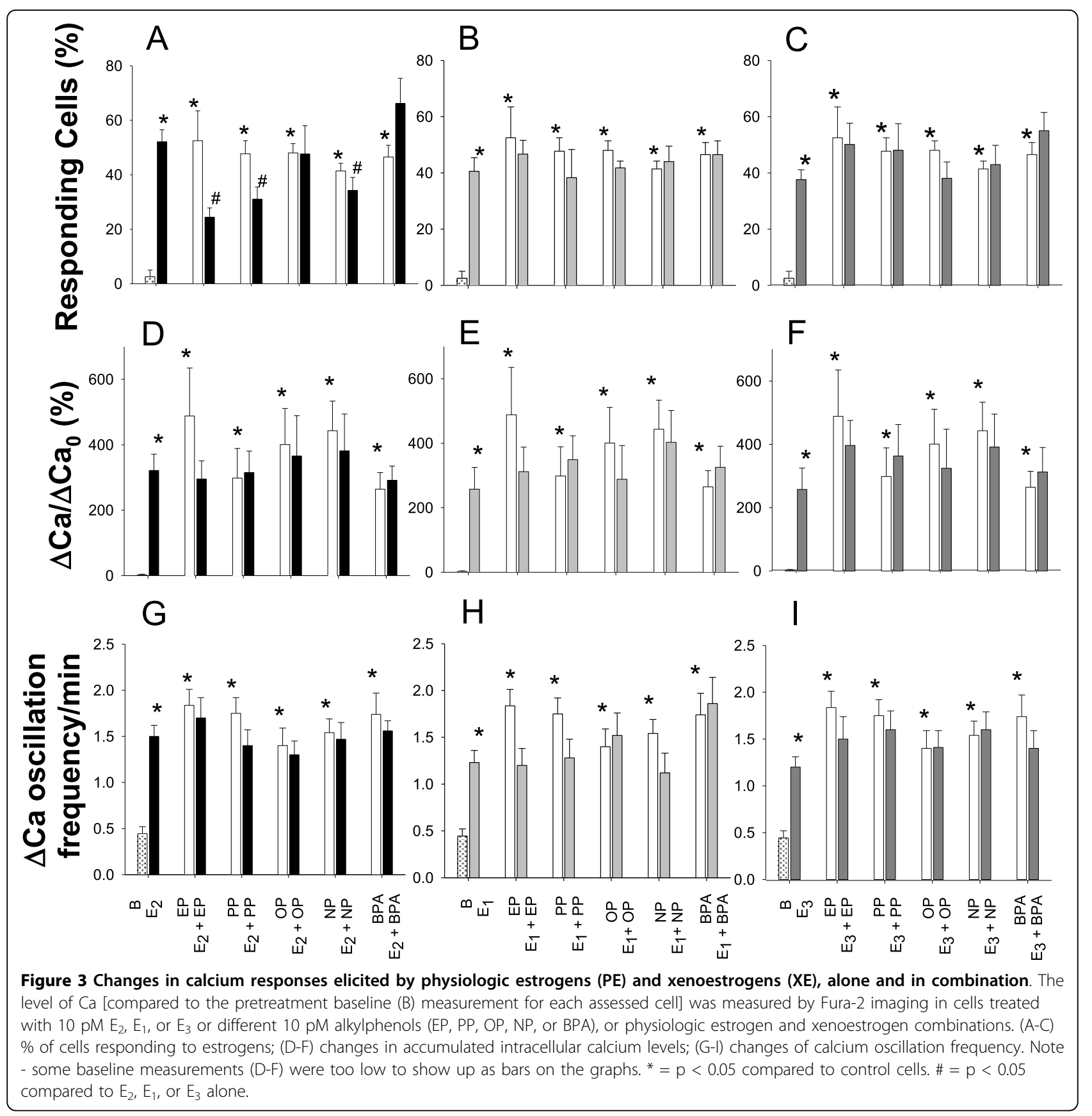

The number of cells in each well was estimated by the crystal violet assay (see below) and used to normalize signals.

The membrane localization of ERs is based on preventing cell permeabilization by careful optimization of fixation and handling techniques for a given cell type. For measurements of mERs, the detergent permeabilization step (above) was left out and the status of the cells' permeabilization was measured by probing with $\mathrm{Ab}$ to clathrin (residing just under the plasma membrane); a low clathrin signal indicates intact cells [73]. Primary Abs were used at 1:1000 for ER $\alpha$ Ab, 1:2000 for ER $\beta$ $\mathrm{Ab}, 1: 1000$ for GPER Ab, and 1:400 for clathrin Ab.

\section{Prolactin assay}

Cells $\left(0.5-0.7 \times 10^{6}\right)$ were plated in poly-D-lysine-coated well of six-well plates. After serum deprivation in 1\% charcoal-stripped $(4 \times)$ serum for $48 \mathrm{~h}$, this medium was removed and DMEM/0.1\% BSA with hormone or the appropriate vehicle control (ethanol) was added. The 
cells were incubated for 2 min and centrifuged at $4{ }^{\circ} \mathrm{C}$ $(350 \times g, 5 \mathrm{~min})$, and the supernatant was collected and stored at $-20^{\circ} \mathrm{C}$. The PRL concentrations were determined using components of the rat PRL RIA kit from the National Institute of Diabetes and Digestive and Kidney Disease and the National Hormone and Pituitary Program (Baltimore, MD). Briefly, RIA buffer (80\% PBS, $20 \%$ DMEM, $2 \%$ normal rabbit serum), $100 \mu \mathrm{L}$ cold standard (rat PRL-RP-3) or unknown sample, rPRL-s-9 antiserum (final dilution of $1: 437,500$ in RIA buffer), and $\left[{ }^{125} \mathrm{I}\right]$-rat-PRL (PerkinElmer, Wellesley, MA; 15,000 counts diluted in RIA buffer) were combined and incubated overnight at $4^{\circ} \mathrm{C}$. Anti-rabbit IgG (Sigma) was added to a final dilution of $1: 9$, and the samples were incubated at RT for $2 \mathrm{hr}$. Then $1 \mathrm{~mL}$ of polyethylene glycol solution (1.2 M polyethylene glycol, $50 \mathrm{mM}$ Tris, $\mathrm{pH}$ 8.6) was added and samples were incubated at RT for $15 \mathrm{~min}$. After centrifugation at $4,000 \times g$ for $10 \mathrm{~min}$ at $4^{\circ} \mathrm{C}$, the supernatant was decanted and the pellet was counted in a Wizard 1470 Gamma Counter (PerkinElmer, Boston, MA). The PRL concentration was then normalized to the crystal violet $(\mathrm{CV})$ values (estimates of the number of cells in each well). These measurements $(n=18)$ were done in 3 different experiments on different days using different passages of cells.

\section{Crystal violet assay}

After being processed for the ERK, mER, and PRL assays, cells were washed $3 \times$ with PBS to remove media or para-nitrophenol and stained with $0.1 \%$ crystal violet solution for $30 \mathrm{~min}$, then destained in deionized water. The dye was then released with $10 \%$ acetic acid, and the $A_{590}$ signal of the extract was read in a model 1420 Wallace microplate reader [74]. The crystal violet assay has been shown previously to correlate well with other cell counting methods [75] and is used for its convenience of combining with our other assays in this study.

\section{Statistics}

Data from $\left[\mathrm{Ca}^{2+}\right] \mathrm{i}, \mathrm{pERK}, \mathrm{mER}$, and PRL studies were analyzed by one-way analysis of variance (ANOVA), followed by multiple comparisons vs. control group (Holm-Sidak method). Experiments were repeated at least 2-3 times using different passages of cells on different days. The Sigma Stat 3 program (Systat Software, Inc.) was used for all statistical analysis, and significance was accepted at $\mathrm{p}<0.05$.

\section{Results}

We previously observed that initial estrogenic triggering of $\mathrm{Ca}$ influx into cells occurred at the same level for all effective estrogen concentrations - an all-or-none response [15,17]. (This is different from the other graduated responses seen when escalating estrogen concentrations are presented to the same cells [19]). Therefore we chose only one active low concentration for all estrogenic compounds (10 pM) to represent a very low and common contamination level. We reasoned that such a low but effective concentration could best make the point regarding concern about prevalent environmental contamination levels.

We measured the portion of cells that respond with increases in Ca spiking (\%, Figure $3 \mathrm{~A}-\mathrm{C}$ ), the accumulated $\mathrm{Ca}$ levels in responding cells $\left(\Delta \mathrm{Ca} / \Delta \mathrm{Ca}_{0}\right.$, Figure $3 \mathrm{D}-\mathrm{F}$ ), and the $\mathrm{Ca}$ oscillation frequency ( $\Delta \mathrm{Ca}$ oscillation, Figure 3G-I). All estrogens, both physiologic and nonphysiologic, caused substantial responses in all three types of $\mathrm{Ca}$ response measurements, as we have observed previously [15]. Only the percentage of cells responding to $\mathrm{E}_{2}$ was altered by combinations of physiologic estrogens with xenoestrogens. Attenuation was caused by combinations with $10 \mathrm{pM}$ EP, PP, or NP, but not OP or BPA. Whether higher concentrations can affect this and other parameters of Ca signaling studied here will require further study.

Using higher through-put assays (in multi-well plates for the ERK and PRL studies), we tested multiple estrogen concentrations. Figures 4 and 5 show how combinations of two different endogenous estrogen concentrations with two different concentrations of each xenoestrogen (10 pM and $1 \mathrm{nM}$ for all estrogens) can affect ERK activation and PRL release. These low concentrations of xenoestrogens correspond to $\sim 20 \mathrm{ppb}$ for the $1 \mathrm{nM}$ concentration, and $200 \mathrm{ppt}$ for the $10 \mathrm{pM}$ concentration. They were chosen to represent high and low values of serum and urine levels reported in Americans [34]. For comparison, physiologic estrogens are present in these assays at $\sim 27 \mathrm{ppb}$ and $270 \mathrm{ppt}$ concentrations.

In the ERK activation assays (Figure 4) both concentrations of all physiologic estrogens evoked responses. Only short-chain alkylphenols (EP and PP), and sometimes BPA activated ERK; (all showed increased activity, but not all instances were statistically significant). Xenoestrogens often blocked physiologic estrogen activation, especially when the higher concentrations of both estrogens were present (J-L). Demonstrating the non-monotonic behavior of xenoestrogen responses, low concentrations were sometimes more effective (disruptive of this response) than higher concentrations (compare A-F with G-L). The ability of BPA to disrupt depended upon whether it was balanced with an equal concentration of its paired physiologic estrogen (compare A-C and J-L, with D-I). In these concentration scenarios, xenoestrogens never significantly enhanced a physiologic estrogen response, as we have sometimes seen at other concentrations [76]. There are many instances where though a concentration of a long-chain 


\section{IOPE-IOXE}

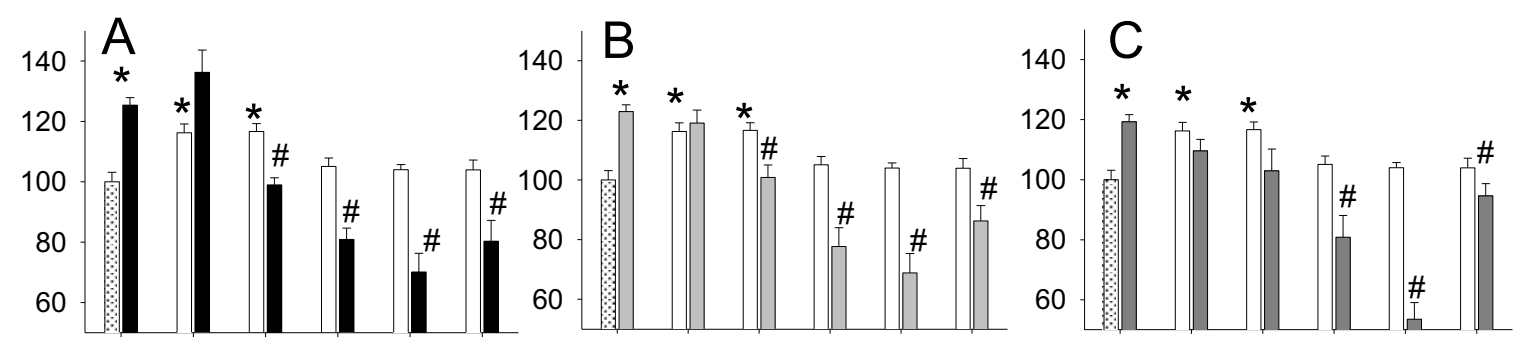

hiPE-IOXE
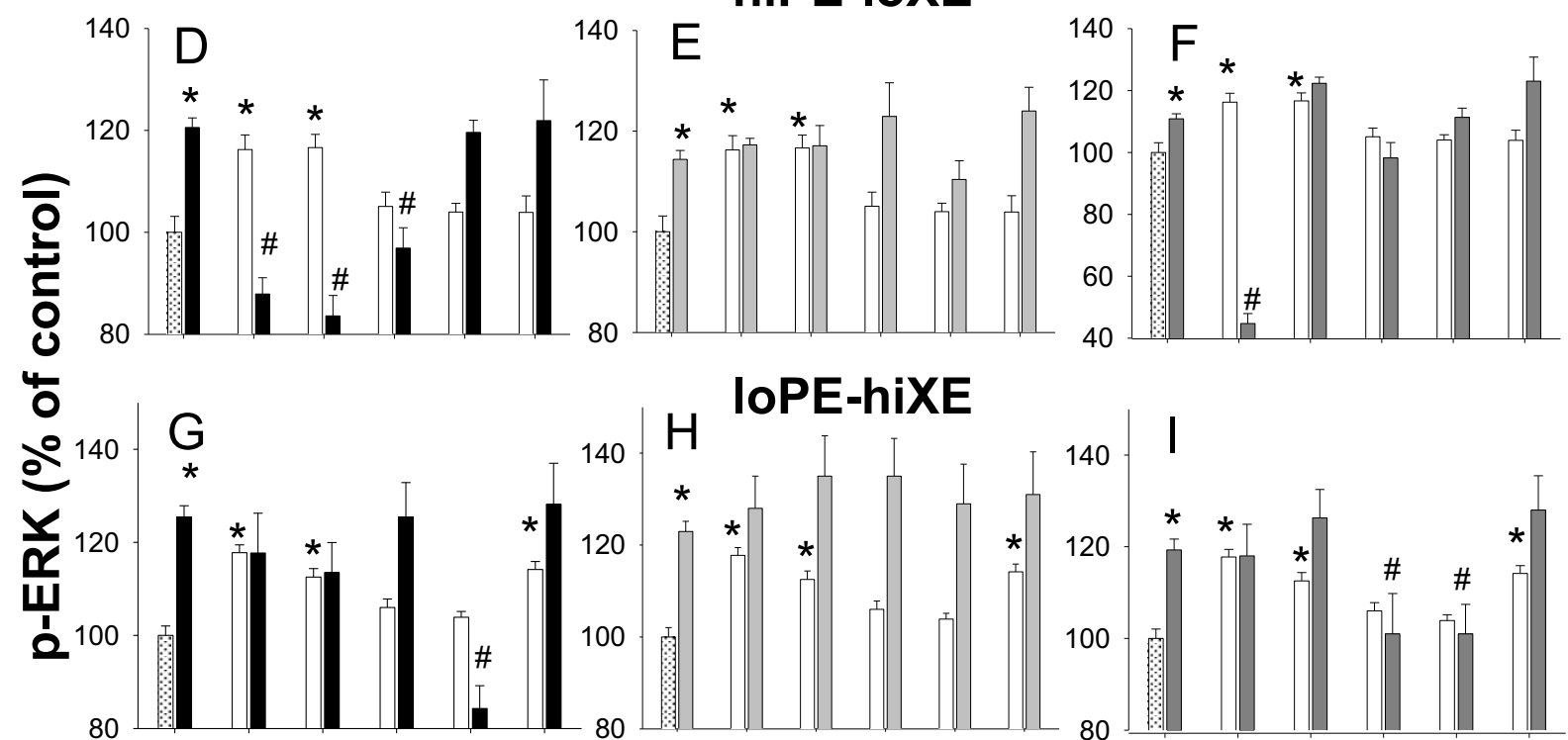

hiPE-hiXE

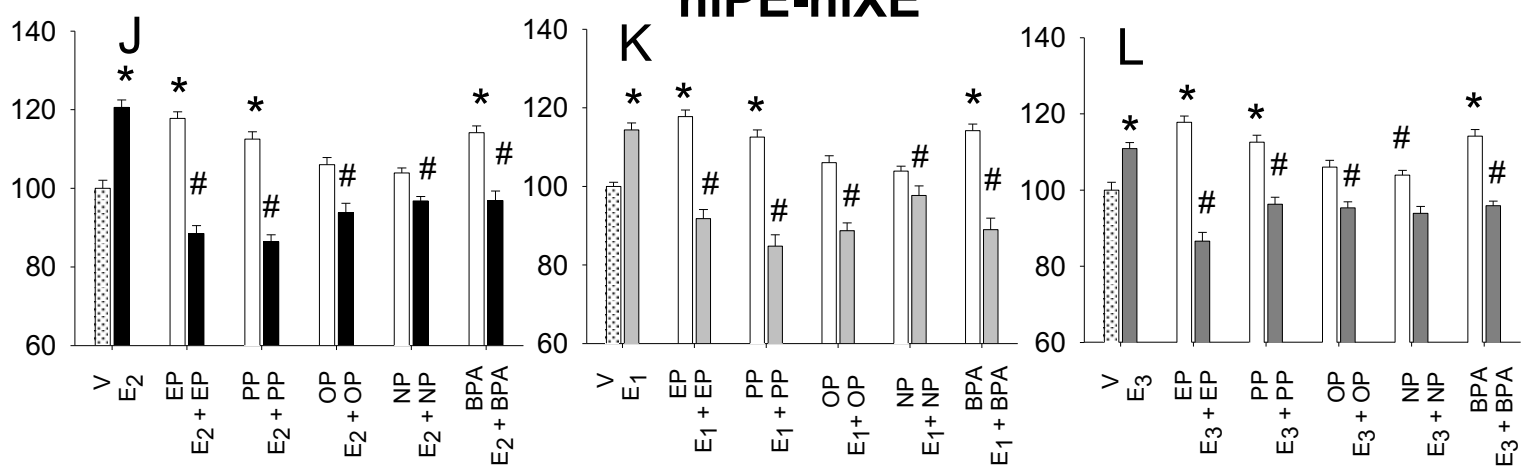

Figure 4 Changes in pERK levels elicited by physiologic estrogens (PE) and xenoestrogens (XE), alone and in combination. The levels of activated ERKs (pERK) were measured in cells treated with (A-C) $10 \mathrm{pM}$ of the physiologic estrogens $\left(E_{2}, E_{1}\right.$, or $\left.E_{3}\right)$ alone or in combinations with $10 \mathrm{pM}$ of different alkylphenols (EP, PP, OP, NP, or BPA), row labeled lo PE - lo XE; (D-F) 1 nM of the physiologic estrogens alone or in combinations with $10 \mathrm{pM}$ of different alkylphenols, row labeled hi PE - lo XE; (G-I) 10 pM of the physiologic estrogens alone or in combinations with $1 \mathrm{nM}$ of different alkylphenols, row labeled lo PE - hi XE; (J-L) $1 \mathrm{nM}$ of the physiologic estrogens alone or in combinations with $1 \mathrm{nM}$ of different alkylphenols, row labeled hi PE - hi XE. ${ }^{*}=p<0.05$ compared to vehicle $(V)$ control cells. $\#=p<0.05$ compared to $E_{2}$, $E_{1}$, or $E_{3}$ alone.

alkylphenol or BPA was not active by itself, it could nevertheless inhibit the paired physiologic estrogen's response (seen in all panels except E, F, and H). In general, our data indicate that both high and low endogenous hormone levels are vulnerable to even extremely low xenoestrogen exposures, so both developing and adult females, and males, could be affected by these xenoestrogens.

In the PRL assays (Figure 5), both concentrations of all physiologic estrogens evoked responses, except that 


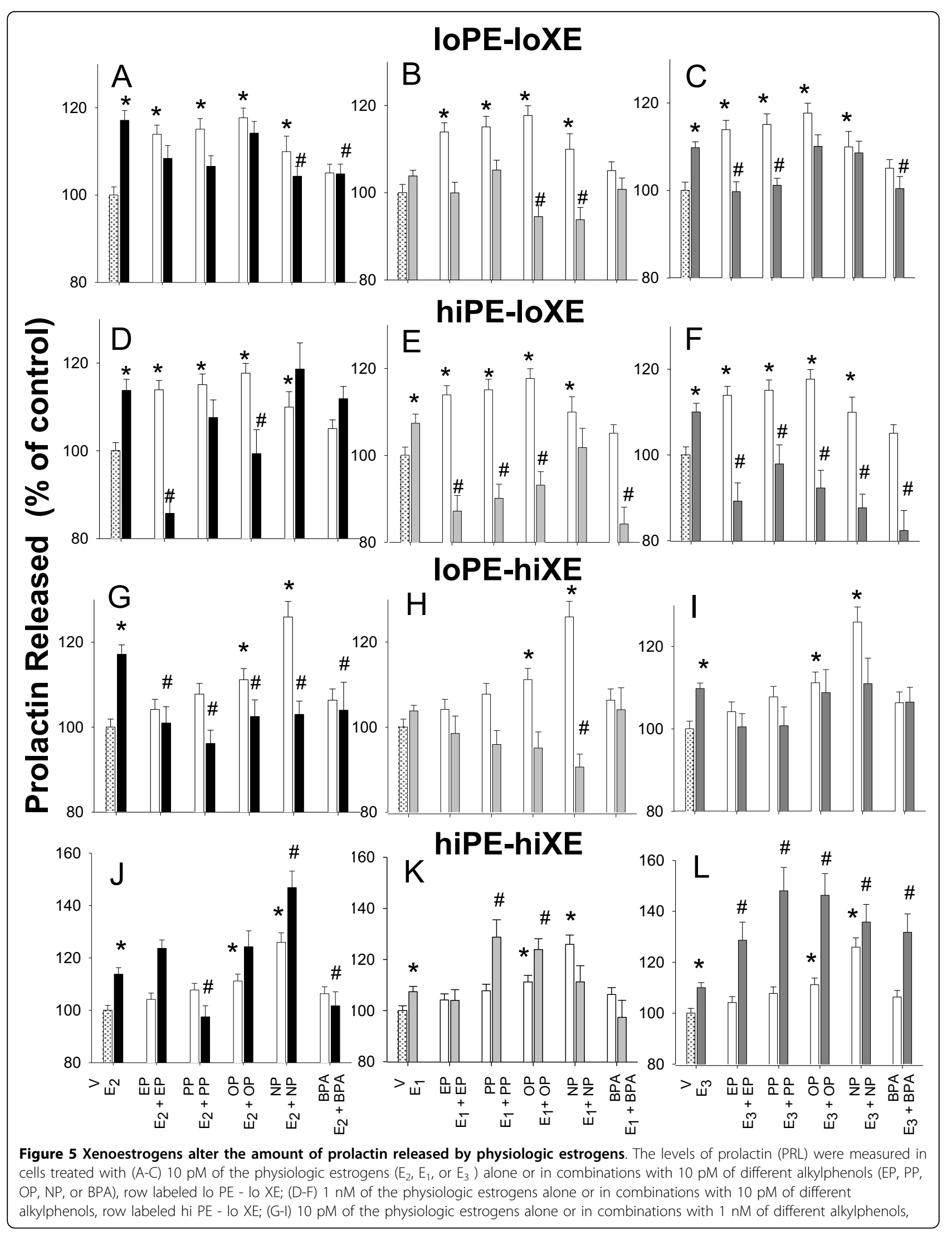


$\mathrm{E}_{1}$ did not always cause a significant change (see B and $\mathrm{H})$. Alkylphenols always evoked PRL release at the lower (pM) concentration (panels A-F), but only the longchain alkylphenols caused this response at the higher (nM) concentration, indicating a non-monotonic behavior of the short-chain alkylphenols. BPA did not cause a response on its own at either of these concentrations, though it has been observed to be active at other concentrations in this response [15,19].

Next we directed our attention to the ability of xenoestrogens to alter the release of PRL elicited by physiologic estrogens. Both short-chain and long-chain alkylphenols were able to block physiologic estrogen responses at either high or low concentrations, intermittently across this range of studies. Interestingly, when both xenoestogens and physiologic estrogens were at the higher (nM) concentration, the effect was more often an enhanced release of PRL (panels J-L). Though not active by itself at these concentrations, BPA could disrupt some physiologic estrogen actions across all paired compound concentrations, and was able to enhance release when its $1 \mathrm{nM}$ concentration was paired with a $1 \mathrm{nM} \mathrm{E}_{3}$ concentration (panel L). Therefore, both of the tested endogenous hormone levels were again vulnerable to alteration.

While for the ERK activations, xenoestrogens always caused inhibition of the response, for the PRL release response, $1 / 3$ of the time the effect was instead enhancement of the response (all at the adult endogenous estrogen levels in combination with $\mathrm{nM}$ xenoestrogens). The chain length of the alkylphenols had some influence, even if differently, on these combinatorial responses with physiologic estrogens, though they were not as pronounced as the previous structure-based effects we saw when these xenoestrogens were administered alone $[1,15]$. Overall, our stringent analysis by ANOVA did not show significance of some effects that would have been judged significant by a student's t-test. However, one can often see trends in the "non-significant" data that still support these conclusions.

Finally, we studied the effects of all of these estrogens on mER trafficking five minutes after hormone administration (Figure 6), choosing this time because it is unambiguously nongenomic, and because five-min responses were universally present for both ERK and $\mathrm{Ca}$ signaling pathways, and for the PRL secretion endpoint, for all classes of estrogens $[1,15]$. We had previously reported the lack of ER $\beta$ in our cell line [37], as values were not significantly different from controls (but did have wide errors of measurement). Perhaps due to assay improvements, cell line evolution, or change of $\mathrm{Ab}$, we now see measurable amounts of ER $\beta$ in the membrane of these $\mathrm{GH}_{3} / \mathrm{B} 6 / \mathrm{F} 10$ cells; whole cell ER $\beta$ had been reported by others in the parent $\mathrm{GH}_{3}$ cell line previously [77]. We detect a $57 \mathrm{kD}$ band for ER $\beta$ on an immunoblot at the same migration distance as ER $\beta$ isolated from LNCAP human prostate cancer cells (data not shown). Some xenoestrogen effects were seen at the 10 pM concentrations for most compounds; OP, NP and BPA all decreased $m E R \alpha$, and PP decreased mER $\beta$. However, these effects were more prominent at the higher $(1 \mathrm{nM})$ concentrations for all compounds. EP, PP, and BPA all decreased mER $\alpha$ in the membrane; all alkylphenols and BPA decreased mER $\beta$ in the membrane. It is interesting that physiologic estrogens also had some effects on

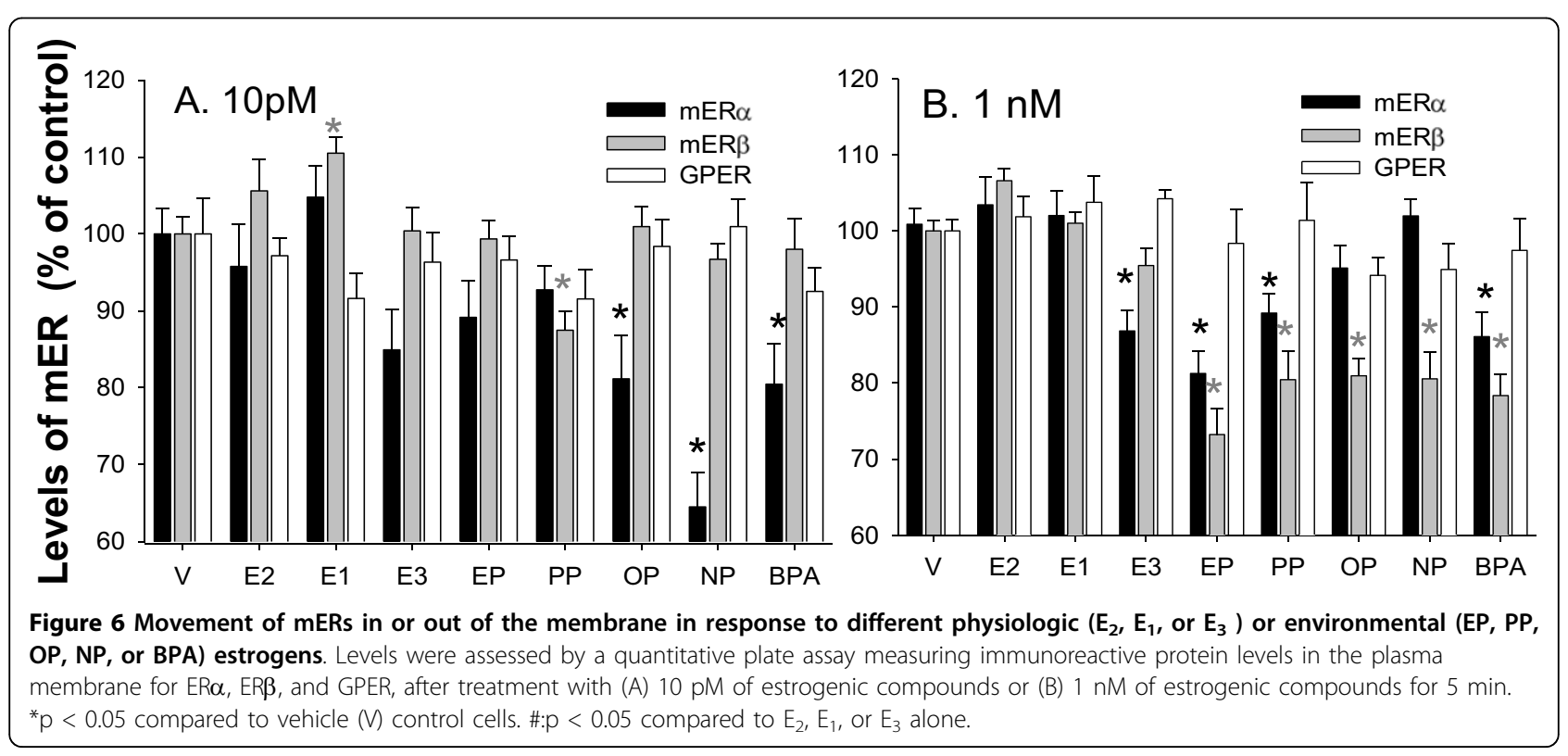


these mERs. $E_{1}$, 『increased levels of $\operatorname{mER} \beta$ at the lower concentration and $E_{3}$ decreased levels of $\operatorname{mER} \alpha$ at the higher concentration. None of these estrogens significantly changed GPER levels.

To validate that our measured receptor antigens were in the membrane, and not the cell interior, we monitored our fixation conditions for absence from accidental plasma membrane disruption. To do this, we examined clathrin $\mathrm{Ab}$ recognition [73], expecting very low levels of this intracellular antigen in unpermeabilized cells. Here we saw a pNP/CV value of $0.035 \pm$ 0.002 for clathrin in unpermeabilized cells compared to $0.16 \pm 0.004$ for permeabilized cells, a 4.6 -fold higher value in permeabilized cells, as expected.

\section{Discussion}

It is clear from our studies that combining xenoestrogens with different physiologic estrogens $\left(E_{1}, E_{2}\right.$, and $\left.E_{3}\right)$ alters responses driven by life-stage-specific levels of the endogenous estrogens. In some cases this caused inhibition of the physiologic response, while in others it caused enhancement. When xenoestrogens disrupt (either inhibit or enhance) estrogenic signaling, then development, menstrual cycling, pregnancy, or postmenopausal maintenance of estrogenic responses could all be altered. Life stage-inappropriate responses could terminate a pregnancy, cause infertility, cause birth defects, or alter pituitary-dependent regulation. Exacerbation of the known tumor-causing effects of estrogens could also be a toxic outcome. In all cases, the affected organism or population would function differently, and would likely be harmed.

Many tissues in both men and women have ERs. Besides the pituitary and reproductive organs, many other systems (eg. bone, brain, heart) could be negatively affected by the interference of xenoestrogen actions with physiologic estrogens. Functioning might be changed directly at the level of the ER-containing tissue, or via downstream activities (such as PRL released from the pituitary and then acting on other tissues). Many other tissues can be indirectly affected or need coordinate regulation by estrogenic actions because they are involved in supporting downstream reproductive functions. For example, pregnancy puts stress on bones due to weight gain, increases nutritional needs via the gut and associated metabolic organs, increases cardiovascular load, requires changes in behaviors, and must suspend some immune system responses to foreign (fetal) antigens. There are several tissues related to such changes upon which xenoestrogens have been reported to have effects at low concentrations [3,4,8-10,78]. Male reproductive and accessory glands also have ERs, and xenoestrogens have been shown to affect the size and function of these organs $[79,80]$.
The levels of physiologic estrogens we have examined here represent those at two very vulnerable life stages. The low $(10 \mathrm{pM})$ levels would be commensurate with an infant or young undeveloped male or female long before hormone levels rise at puberty. Certainly environmental estrogens could have an impact at this stage, when endogenous estrogens have not begun to rise to the high levels required for reproductive tissue development and function. The second level that we examined (1 nM) typifies cycling females and early pregnancy, and so would represent vulnerabilities to women during their reproductive years. The levels of xenoestrogens we studied represent those amounts expected to be present in the majority of Americans according to the values reported by the NHANES database $[34,81]$ for human blood and urine, and are probably similar in inhabitants of other developed countries. Exposures to xenoestrogens, especially at the low doses that we study (10 pM$\mathrm{nM}$ or $0.2-20 \mathrm{ppb}$ ), are therefore quite common as a result of present-day environmental exposures. We see evidence of non-monotonic dose-response behaviors throughout our study results, a pattern that is now recognized as typical of environmental and physiological estrogen actions via the nongenomic pathways. The hormesis effect [82] is somewhat evident here, where the more potent are estrogenic effects, the greater is the potential for inhibition of those effects at higher exposure levels, in this case exacerbated by the combination of estrogens. However, we can see these effects more prominently in other studies where more detailed dose responses were monitored [83]. Hormetic inhibitions are very common in hormonal responses of many kinds, and are thought by some to be safety mechanisms to prevent overstimulation. It appears that for the purposes of adding up the stimuli leading to signal integration at the level of the MAPKs [1], both physiologic and nonphysiologic estrogens contribute to the final count, perhaps pushing the total into the overstimulation range.

The mediators of these nongenomic responses are mERs, so it is important to understand if their levels in the membrane changed with these treatments. We had previously observed such movements of mERs in and out of the membrane in PC12 neuronal cells [13,14]; our findings there were consistent with the increased presence of $\mathrm{mER} \alpha$ in the membrane as the primary mediator of estrogen-induced dopamine efflux from these cells via the dopamine transporter. $\operatorname{mER} \beta$ and GPER acted to mediate inhibition of this response, and were consequently removed from the membrane under the influence of a variety of estrogens that enhanced dopamine effux. It is also possible that these receptors do not actually leave the membrane, but may be shifted to an inactive conformation that epitope-specific Abs to ERs no longer recognize. However, that is not likely 
with the Abs we used, because such conformational transformations affecting $\mathrm{Ab}$ recognition usually only occur in the hinge region epitopes of ERs $[84,85]$, and here we used Abs recognizing the carboxy terminus. The physiologic estrogens $E_{1}$ and $E_{3}$ also altered the number of membrane ER $\beta$ s and ER $\alpha$ s, respectively, so this may represent life stage-specific modulation of physiologic functions by rapid movement of receptors in and out of the membrane, a way for one endogenous hormone to influence the actions of others. Because alkylphenols and BPA dramatically downregulated $\mathrm{mER} \alpha$ and $\beta$ in the membrane, especially at the higher (nM) concentrations, it seems that this could be one of the primary mechanisms of their actions. Even though xenoestrogens did not affect GPER levels in the membrane in our study, several have been shown to bind to GPERs expressed by transfection in HEK293 cells [86]. Interestingly, $\mathrm{E}_{3}$ has recently been shown to be an antagonist at GPER, though it does not alter the presence of GPER in the membrane [87].

Trafficking actions would not only affect the signaling and functional responses to xenoestrogens at this rapid time point, but also have consequences for the subsequent actions of physiologic estrogens via these receptors. Where these receptors go, or when they return, is not addressed by our studies, but others have suggested that dynamic movement in and out of the membrane is part of the necessary cycling that supports estrogenic functions in a variety of tissues $[88,89]$.

\section{Conclusions}

By designing medium-throughput, quantitative assays to assess multiple nongenomic responses, we have been able to compare the potencies and efficacies of several structurally related xenoestrogens for important parameters of signaling, function, and receptor trafficking in pituitary cells. In contrast to their weak actions via genomic signaling pathways, these compounds are profoundly effective in disrupting nongenomic responses to multiple endogenous estrogens at concentrations that represent different life stages. These mechanistic explanations for the activities of xenoestrogens at low concentrations help explain their actions on the functions of exposed animals and humans both during development and in reproductive adulthood, and confirm our concern about continuing to allow such xenoestrogens to contaminate our environment.

\section{List of abbreviations}

(EP): 4-n-ethylphenol; (NP): 4-n-nonylphenol; (OP): 4-n-octylphenol; (PP): 4-npropylphenol; (Ab): antibody; (BPA): bisphenol A; (Ca): calcium; ( $\left.E_{2}\right)$ : estradiol; $\left(E_{3}\right)$ : estriol; $\left(E_{1}\right)$ : estrone; $(E R)$ : estrogen receptor; (ERKs): extracellular-signal regulated kinases; (mERs): membrane estrogen receptors; (MAPKs): mitogenactivated protein kinases; (PRL): prolactin

\section{Competing interests}

The authors declare that they have no competing interests.

\section{Authors' contributions}

YJJ carried out the PRL, mER, and kinase experiments in these studies. MYK performed the imaging studies of intracellular Ca. All authors participated in the design and analyses of the studies, and wrote, read, and approved the final manuscript.

\section{Acknowledgements}

This work was supported by National Institute of Health, grant R01 ES015292. The authors acknowledge the expert skills of Dr. David Konkel, who helped with the editing of our paper.

Received: 7 July 2010 Accepted: 15 October 2010

Published: 15 October 2010

\section{References}

1. Watson CS, Jeng YJ, Kochukov MY: Nongenomic signaling pathways of estrogen toxicity. Toxicol Sci 2010, 115:1-11.

2. Alonso-Magdalena $P$, Laribi $O$, Ropero $A B$, Fuentes $E$, Ripoll $C$, Soria $B$, Nadal A: Low doses of bisphenol A and diethylstilbestrol impair $\mathrm{Ca} 2+$ signals in pancreatic alpha-cells through a nonclassical membrane estrogen receptor within intact islets of Langerhans. Environ Health Perspect 2005, 113:969-977.

3. Della SD, Minder I, Dessi-Fulgheri F, Farabollini F: Bisphenol-A exposure during pregnancy and lactation affects maternal behavior in rats. Brain Res Bull 2005, 65:255-260.

4. Fujimoto T, Kubo K, Aou S: Prenatal exposure to bisphenol A impairs sexual differentiation of exploratory behavior and increases depressionlike behavior in rats. Brain Res 2006, 1068:49-55.

5. Jones DC, Miller GW: The effects of environmental neurotoxicants on the dopaminergic system: A possible role in drug addiction. Biochem Pharmacol 2008, 76:569-581.

6. Kabil A, Silva E, Kortenkamp A: Estrogens and genomic instability in human breast cancer cells-involvement of Src/Raf/Erk signaling in micronucleus formation by estrogenic chemicals. Carcinogenesis 2008, 29:1862-1868.

7. Kiguchi M, Fujita S, Oki H, Shimizu N, Cools AR, Koshikawa N: Behavioural characterisation of rats exposed neonatally to bisphenol-A: responses to a novel environment and to methylphenidate challenge in a putative model of attention-deficit hyperactivity disorder. J Neural Transm 2008, 115:1079-1085

8. Midoro-Horiuti T, Tiwari R, Watson CS, Goldblum RM: Maternal bisphenol a exposure promotes the development of experimental asthma in mouse pups. Environ Health Perspect 2010, 118:273-277.

9. Munoz-de-Toro M, Markey C, Wadia PR, Luque EH, Rubin BS, Sonnenschein C, Soto AM: Perinatal exposure to Bisphenol A alters peripubertal mammary gland development in mice. Endocr 2005.

10. Nadal A, Alonso-Magdalena P, Soriano S, Quesada I, Ropero AB: The pancreatic beta-cell as a target of estrogens and xenoestrogens: Implications for blood glucose homeostasis and diabetes. Mol Cell Endocrinol 2009, 304:63-68.

11. Suzuki T, Mizuo K, Nakazawa H, Funae Y, Fushiki S, Fukushima S, Shirai T, Narita M: Prenatal and neonatal exposure to bisphenol-A enhances the central dopamine D1 receptor-mediated action in mice: enhancement of the methamphetamine-induced abuse state. Neuroscience 2003, 117:639-644

12. Watson CS, Jeng YJ, Kochukov MY: Nongenomic actions of estradiol compared with estrone and estriol in pituitary tumor cell signaling and proliferation. FASEB J 2008, 22:3328-3336.

13. Alyea RA, Watson CS: Nongenomic mechanisms of physiological estrogen-mediated dopamine efflux. BMC Neurosci 2009, 10:59.

14. Alyea RA, Watson CS: Differential regulation of dopamine transporter function and location by low concentrations of environmental estrogens and 17beta-estradiol. Environ Health Perspect 2009, 117:778-783.

15. Kochukov MY, Jeng YJ, Watson CS: Alkylphenol xenoestrogens with varying carbon chain lengths differentially and potently activate signaling and functional responses in $\mathrm{GH}_{3} / \mathrm{B}_{6} / \mathrm{F} 10$ somatomammotropes. Env Health Perspect 2009, 117:723-730. 
16. Jeng YJ, Watson CS: Proliferative and anti-proliferative effects of dietary levels of phytoestrogens in rat pituitary GH3/B6/F10 cells - the involvement of rapidly activated kinases and caspases. BMC Cancer 2009, 9:334.

17. Jeng YJ, Kochukov MY, Watson CS: Membrane estrogen receptor-alphamediated nongenomic actions of phytoestrogens in GH3/B6/F10 pituitary tumor cells. J Mol Signal 2009, 4:2

18. Bulayeva NN, Watson CS: Xenoestrogen-induced ERK-1 and ERK-2 activation via multiple membrane-initiated signaling pathways. Environ Health Perspect 2004, 112:1481-1487.

19. Wozniak AL, Bulayeva NN, Watson CS: Xenoestrogens at picomolar to nanomolar concentrations trigger membrane estrogen receptor-alphamediated $\mathrm{Ca} 2+$ fluxes and prolactin release in $\mathrm{GH} 3 / \mathrm{B} 6$ pituitary tumor cells. Environ Health Perspect 2005, 113:431-439.

20. Gaido KW, Leonard LS, Lovell S, Gould JC, Babai D, Portier CJ, McDonnell DP: Evaluation of chemicals with endocrine modulating activity in a yeast-based steroid hormone receptor gene transcription assay. Toxicol Appl Pharmacol 1997, 143:205-212.

21. Gutendorf B, Westendorf J: Comparison of an array of in vitro assays for the assessment of the estrogenic potential of natural and synthetic estrogens, phytoestrogens and xenoestrogens. Toxicology 2001 166:79-89.

22. Steinmetz R, Brown NG, Allen DL, Bigsby RM, Benjonathan N: The environmental estrogen bisphenol $A$ stimulates prolactin release in vitro and in vivo. Endocr 1997, 138:1780-1786.

23. Kloas W, Lutz I, Einspanier R: Amphibians as a model to study endocrine disruptors: II. Estrogenic activity of environmental chemicals in vitro and in vivo. Sci Total Environ 1999, 225:59-68.

24. Sheeler CQ, Dudley MW, Khan SA: Environmental estrogens induce transcriptionally active estrogen receptor dimers in yeast: activity potentiated by the coactivator RIP140. Environ Health Perspect 2000, 108:97-103.

25. Singleton DW, Feng $Y$, Chen $Y$, Busch SJ, Lee AV, Puga A, Khan SA: Bisphenol-A and estradiol exert novel gene regulation in human MCF-7 derived breast cancer cells. Mol Cell Endocrinol 2004, 221:47-55.

26. Ikezuki Y, Tsutsumi O, Takai Y, Kamei Y, Taketani Y: Determination of bisphenol A concentrations in human biological fluids reveals significant early prenatal exposure. Human Reproduction 2002, 17:2839-2841.

27. Inoue $K$, Yoshimura Y, Makino T, Nakazawa H: Determination of 4nonylphenol and 4-octylphenol in human blood samples by highperformance liquid chromatography with multi-electrode electrochemical coulometric-array detection. Analyst 2000, 125:1959-1961.

28. Kawaguchi M, Inoue K, Sakui N, Ito R, Izumi S, Makino T, Okanouchi N, Nakazawa H: Stir bar sorptive extraction and thermal desorption-gas chromatography-mass spectrometry for the measurement of 4nonylphenol and 4-tert-octylphenol in human biological samples. $J$ Chromatogr B Analyt Technol Biomed Life Sci 2004, 799:119-125.

29. Takeuchi T, Tsutsumi O: Serum bisphenol A concentrations showed gender differences, possibly linked to androgen levels. Biochem Biophys Res Commun 2002, 291:76-78.

30. Petrovic M, Diaz A, Ventura F, Barcelo D: Occurrence and removal of estrogenic short-chain ethoxy nonylphenolic compounds and their halogenated derivatives during drinking water production. Environ $\mathrm{SCl}$ Technol 2003, 37:4442-4448.

31. Kolpin DW, Furlong ET, Meyer MT, Thurman EM, Zaugg SD, Barber LB, Buxton HT: Pharmaceuticals, hormones, and other organic wastewater contaminants in U.S. streams, 1999-2000: a national reconnaissance. Environ Sci Technol 2002, 36:1202-1211.

32. Bonefeld-Jorgensen EC, Long M, Hofmeister MV, Vinggaard AM: Endocrinedisrupting potential of bisphenol A, bisphenol A dimethacrylate, 4-nnonylphenol, and 4-n-octylphenol in vitro: new data and a brief review. Environ Health Perspect 2007, 115(Suppl 1):69-76.

33. Calafat AM, Kuklenyik Z, Reidy JA, Caudill SP, Ekong J, Needham LL: Urinary concentrations of bisphenol $A$ and 4-nonylphenol in a human reference population. Environ Health Perspect 2005, 113:391-395.

34. Lakind JS, Naiman DQ: Bisphenol A (BPA) daily intakes in the United States: estimates from the 2003-2004 NHANES urinary BPA data. J Expo Sci Environ Epidemiol 2008, 18:608-615.

35. Benoff S: Modeling human sperm-egg interactions in vitro - signal transduction pathways regulating the acrosome reaction. Molecular Human Reproduction 1998, 4:453-471.
36. Razandi M, Pedram A, Levin ER: Plasma membrane estrogen receptors signal to antiapoptosis in breast cancer. Mol Endocrinol 2000, 14:1434-1447.

37. Campbell CH, Bulayeva N, Brown DB, Gametchu B, Watson CS: Regulation of the membrane estrogen receptor-alpha: role of cell density, serum, cell passage number, and estradiol. FASEB J 2002, 16:1917-1927.

38. Norfleet AM, Thomas ML, Gametchu B, Watson CS: Estrogen receptor-a detected on the plasma membrane of aldehyde-fixed GH3/B6/F10 rat pituitary cells by enzyme-linked immunocytochemistry. Endocr 1999, 140:3805-3814.

39. Pappas TC, Gametchu B, Watson CS: Membrane estrogen receptors identified by multiple antibody labeling and impeded-ligand binding. FASEB J 1995, 9:404-410.

40. Acconcia F, Ascenzi P, Bocedi A, Spisni E, Tomasi V, Trentalance A, Visca P, Marino M: Palmitoylation-dependent estrogen receptor alpha membrane localization: regulation by 17 beta-estradiol. Mol Biol Cell 2005, 16:231-237.

41. Marquez DC, Pietras RJ: Membrane-associated binding sites for estrogen contribute to growth regulation of human breast cancer cells. Oncogene 2001, 20:5420-5430.

42. Alyea RA, Laurence SE, Kim SH, Katzenellenbogen BS, Katzenellenbogen JA, Watson CS: The roles of membrane estrogen receptor subtypes in modulating dopamine transporters in PC-12 cells. J Neurochem 2008, 106:1525-1533.

43. Razandi M, Pedram A, Greene GL, Levin ER: Cell membrane and nuclear estrogen receptors (ERs) originate from a single transcript: Studies of ER囚 and ERß expressed in chinese hamster ovary cells. Mol Endocrino 1999, 13:307-319.

44. Thomas P, Alyea R, Pang Y, Peyton C, Dong J, Berg AH: Conserved estrogen binding and signaling functions of the $G$ protein-coupled estrogen receptor 1 (GPER) in mammals and fish. Steroids 2010, 75:595-602.

45. Maggiolini M, Picard D: The unfolding stories of GPR30, a new membrane-bound estrogen receptor. J Endocrinol 2010, 204:105-114.

46. Prossnitz ER, Barton M: Signaling, physiological functions and clinical relevance of the G protein-coupled estrogen receptor GPER. Prostaglandins \& Other Lipid Mediators 2009, 89:89-97.

47. Thomas $P$, Dong J: Binding and activation of the seven-transmembrane estrogen receptor GPR30 by environmental estrogens: a potential novel mechanism of endocrine disruption. J Steroid Biochem Mol Biol 2006, 102:175-179.

48. Belcher SM: Rapid signaling mechanisms of estrogens in the developing cerebellum. Brain Res Rev 2008, 57:481-492.

49. Zsarnovszky A, Le HH, Wang HS, Belcher SM: Ontogeny of rapid estrogenmediated extracellular signal-regulated kinase signaling in the rat cerebellar cortex: potent nongenomic agonist and endocrine disrupting activity of the xenoestrogen bisphenol A. Endocr 2005, 146:5388-5396.

50. Narita S, Goldblum RM, Watson CS, Brooks EG, Estes DM, Curran EM, Midoro-Horiuti T: Environmental estrogens induce mast cell degranulation and enhance lgE-mediated release of allergic mediators. Environ Health Perspect 2007, 115:48-52.

51. Wetherill YB, Akingbemi BT, Kanno J, McLachlan JA, Nadal A, Sonnenschein C, Watson CS, Zoeller RT, Belcher SM: In vitro molecular mechanisms of bisphenol A action. Reprod Toxicol 2007, 24:178-198.

52. Jeng YJ, Kochukov M, Nauduri D, Kaphalia BS, Watson CS: Subchronic exposure to phytoestrogens alone and in combination with diethylstilbestrol - pituitary tumor induction in Fischer 344 rats. Nutr Metab (Lond) 2010, 7:40.

53. Gorski J, Wendell D, Gregg D, Chun TY: Estrogens and the genetic control of tumor growth. [Review] [23 refs]. Progress in Clinical \& Biological Research 1997, 396:233-243.

54. Zhu BT, Liehr JG: Quercetin increases the severity of estradiol-induced tumorigenesis in hamster kidney. Toxicology \& Applied Pharmacology 1994, 125:149-158

55. Ho SM, Tang WY, Belmonte de FJ, Prins GS: Developmental exposure to estradiol and bisphenol A increases susceptibility to prostate carcinogenesis and epigenetically regulates phosphodiesterase type 4 variant 4. Cancer Res 2006, 66:5624-5632.

56. Andrade AJ, Grande SW, Talsness CE, Grote K, Chahoud I: A dose-response study following in utero and lactational exposure to di-(2-ethylhexyl)- 
phthalate (DEHP): non-monotonic dose-response and low dose effects on rat brain aromatase activity. Toxicology 2006, 227:185-192.

57. Alonso-Magdalena P, Morimoto S, Ripoll C, Fuentes E, Nadal A: The estrogenic effect of bisphenol A disrupts pancreatic beta-cell function in vivo and induces insulin resistance. Environ Health Perspect 2006, 114:106-112.

58. Palanza P, Gioiosa L, vom Saal FS, Parmigiani S: Effects of developmental exposure to bisphenol $\mathrm{A}$ on brain and behavior in mice. Environ Res 2008, 108:150-157.

59. Warner KE, Jenkins JJ: Effects of 17alpha-ethinylestradiol and bisphenol A on vertebral development in the fathead minnow (Pimephales promelas). Environ Toxicol Chem 2007, 26:732-737.

60. Watson CS, Norfleet AM, Pappas TC, Gametchu B: Rapid actions of estrogens in $\mathrm{GH}_{3} / \mathrm{B} 6$ pituitiary tumor cells via a plasma membrane

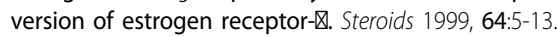

61. Vandenberg LN, Maffini MV, Sonnenschein C, Rubin BS, Soto AM: Bisphenol- $A$ and the great divide: a review of controversies in the field of endocrine disruption. Endocr Rev 2009, 30:75-95.

62. Greenspan FS, Gardner DG: Appendix: Normal Hormone Reference Ranges. In Basic and Clinical Endocrinology. Edited by: Greenspan FS, Gardner DG. New York: Lange Medical Books, McGraw Hill; , 7 2004:925-926.

63. Shenhav S, Gemer O, Volodarsky M, Zohav E, Segal S: Midtrimester triple test levels in women with severe preeclampsia and HELLP syndrome. Acta Obstet Gynecol Scand 2003, 82:912-915.

64. Chard T, Macintosh MC: Screening for Down's syndrome. J Perinat Med 1995, 23:421-436.

65. Meinhardt U, Mullis PE: The essential role of the aromatase/p450arom. Semin Reprod Med 2002, 20:277-284.

66. Jansson L, Holmdahl R: Enhancement of collagen-induced arthritis in female mice by estrogen receptor blockage. Arthritis Rheum 2001, 44:2168-2175.

67. Morley P, Whitfield JF, Vanderhyden BC, Tsang BK, Schwartz J: A new, nongenomic estrogen action: The rapid release of intracellular calcium. Endocr 1992, 131:1305-1312.

68. Selles J, Polini N, Alvarez C, Massheimer V: Novel action of estrone on vascular tissue: regulation of NOS and COX activity. Steroids 2005, 70:251-256.

69. Chambliss KL, Yuhanna IS, Mineo C, Liu P, German Z, Sherman TS, Mendelsohn ME, Anderson RG, Shaul PW: Estrogen receptor alpha and endothelial nitric oxide synthase are organized into a functional signaling module in caveolae. Circ Res 2000, 87:E44-E52.

70. Zivadinovic D, Watson CS: Membrane estrogen receptor-alpha levels predict estrogen-induced ERK1/2 activation in MCF-7 cells. Breast Cancer Res 2005, 7:R130-R144.

71. Razandi M, Oh P, Pedram A, Schnitzer J, Levin ER: ERs associate with and regulate the production of caveolin: Implications for signaling and cellular actions. Mol Endocrinol 2002, 16:100-115.

72. Bulayeva NN, Gametchu B, Watson CS: Quantitative measurement of estrogen-induced ERK 1 and 2 activation via multiple membraneinitiated signaling pathways. Steroids 2004, 69:181-192.

73. Campbell CH, Watson CS: A comparison of membrane vs. intracellular estrogen receptor-alpha in $\mathrm{GH}(3) / \mathrm{B} 6$ pituitary tumor cells using a quantitative plate immunoassay. Steroids 2001, 66:727-736.

74. Lottering ML, Haag M, Seegers JC: Effects of $17 \beta$-estradiol metabolites on cell cycle events in MCF-7 cells. Cancer Res 1992, 52:5926-5932.

75. Zivadinovic D, Gametchu B, Watson CS: Membrane estrogen receptoralpha levels in MCF-7 breast cancer cells predict CAMP and proliferation responses PMCID:15642158. Breast Cancer Res 2005, 7:R101-R112.

76. Jeng YJ, Watson CS: Combinations of physiologic estrogens with xenoestrogens alter ERK phosphorylation profiles in rat pituitary cells. Environ Health Perspect 2010.

77. Mitchner NA, Garlick C, Steinmetz RW, Ben-Jonathan N: Differential regulation and action of estrogen receptors alpha and beta in $\mathrm{GH} 3$ cells. Endocr 1999, 140:2651-2658.

78. Narita M, Miyagawa K, Mizuo K, Yoshida T, Suzuki T: Prenatal and neonatal exposure to low-dose of bisphenol-A enhance the morphine-induced hyperlocomotion and rewarding effect. Neurosci Lett 2006, 402:249-252.

79. vom Saal FS, Cooke PS, Buchanan DL, Palanza P, Thayer KA, Nagel SC, Parmigiani S, Welshons WV: A physiologically based approach to the study of bisphenol A and other estrogenic chemicals on the size of reproductive organs, daily sperm production, and behavior. Toxicol Ind Health 1998, 14:239-260.

80. Welshons W, Nagel SC, vom Saal FS: Large effects from small exposures. III. Endocrine mechanisms mediating effects of bisphenol A at levels of human exposure. Endocr 2006, 147:S56-S69.

81. Stahlhut RW, Welshons WV, Swan SH: Bisphenol A data in NHANES suggest longer than expected half-life, substantial nonfood exposure, or both. Environ Health Perspect 2009, 117:784-789.

82. Weltje L, vom Saal FS, Oehlmann J: Reproductive stimulation by low doses of xenoestrogens contrasts with the view of hormesis as an adaptive response. Hum Exp Toxicol 2005, 24:431-437.

83. Jeng YJ, Watson CS: Combinations of physiologic estrogens with xenoestrogens alter ERK phosphorylation profiles in rat pituitary cells. Environ Health Perspect 2010.

84. Watson CS, Campbell CH, Gametchu B: Membrane estrogen receptors on rat pituitary tumor cells: Immunoidentification and responses to estradiol and xenoestrogens. Experimental Physiology 1999, 84:1013-1022.

85. Norfleet AM, Clarke C, Gametchu B, Watson CS: Antibodies to the estrogen receptor-a modulate prolactin release from rat pituitary tumor cells through plasma membrane estrogen receptors. FASEB J 2000, 14:157-165.

86. Thomas P, Dong J: Binding and activation of the seven-transmembrane estrogen receptor GPR30 by environmental estrogens: a potential novel mechanism of endocrine disruption. J Steroid Biochem Mol Biol 2006, 102:175-179.

87. Lappano R, Rosano C, De MP, De Francesco EM, Pezzi V, Maggiolini M: Estriol acts as a GPR30 antagonist in estrogen receptor-negative breast cancer cells. Mol Cell Endocrinol 2010, 320:162-170.

88. Song RX, Barnes CJ, Zhang Z, Bao Y, Kumar R, Santen RJ: The role of Shc and insulin-like growth factor 1 receptor in mediating the translocation of estrogen receptor alpha to the plasma membrane. Proc Natl Acad Sci USA 2004, 101:2076-2081.

89. Pedram A, Razandi M, Sainson RC, Kim JK, Hughes CC, Levin ER: A conserved mechanism for steroid receptor translocation to the plasma membrane. J Biol Chem 2007, 282:22278-22288.

doi:10.1186/1476-069X-9-61

Cite this article as: Jeng et al:: Combinations of physiologic estrogens with xenoestrogens alter calcium and kinase responses, prolactin release, and membrane estrogen receptor trafficking in rat pituitary cells. Environmental Health 2010 9:61.

\section{Submit your next manuscript to BioMed Central and take full advantage of:}

- Convenient online submission

- Thorough peer review

- No space constraints or color figure charges

- Immediate publication on acceptance

- Inclusion in PubMed, CAS, Scopus and Google Scholar

- Research which is freely available for redistribution

Submit your manuscript at www.biomedcentral.com/submit
Ciomed Central 